\title{
Нікіма Лихачов,
}

аспірант кафедри конституиійного права

Київського національного університету

ім. Т. Шевченка

\section{ПРОЦЕДУРА РЕЗОЛЮЦІЇ (ВОТУМУ) НЕДОВІРИ ЯК ФОРМА ПАРЛАМЕНТСЬКОЇ ВІДПОВІДАЛЬНОСТІ КАБІНЕТУ МIHICТРІВ УКРАЇНИ}

\begin{abstract}
Досліджено парламентську відповідальність Кабінету Міністрів України, зокрема однієї з ї̈ форм резолючії (вотуму) недовіри. Визначено поняття та проаналізовано ознаки парламентської відповідальності уряду Украӥни. Розглянуто процедуру резолющї недовіри Кабінету Міністрів Украӥни.

Ключові слова: уряд, Кабінет Міністрів Украӥни, парламентська відповідальність, резолючія (вотум) недовіри.
\end{abstract}

Лихачов $\mathrm{H}$.

Процедура резолюции (вотума) недоверия как форма парламентской ответственности Кабинета Министров Украины

Исследовано парламентскую ответственность Кабинета Министров Украины, в частности одной из ее форм - резолюиии (вотума) недоверия. Дано понятие и проанализированы признаки парламентской ответственности правительства Украины. Рассмотрена прочедура резолюиия недоверия Кабинету Министров Украиныл.

Ключевые слова: правительство, Кабинет Министров Украинь, парламентская ответственность, резолючия (вотум) недоверия.

Lykhachov $N$.

The procedure of filing the motion (vote) of no confidence as one of the forms of parliamentary responsibility of the Cabinet of Ministers of Ukraine.

This article is conducting a research on parliamentary responsibility of the Cabinet of Ministers of Ukraine - the motion (vote) of no confidence, in particular, as one of its forms. The notion and attributes of parliamentary responsibility of the Ukrainian government are revealed and analysed in the article. In addition, the procedure of filing the motion of no confidence is considered. confidence.

Keywords: government, the Cabinet of Ministers of Ukraine, parliamentary responsibility, motion (vote) of no

Постановка проблеми. Серед найбільших проблем державотворення, які протягом багатьох років не втрачають своєї актуальності, істотне місце займають питання організації та функціонування уряду. Повною мірою це стосується й Кабінету Міністрів України - вищого органу виконавчої влади України. Ефективність функціонування Кабінету Міністрів України залежить великою мірою від наявності дієвих інституціональних механізмів його відповідальності перед Верховною Радою України. Парламентська відповідальність вищого органу виконавчої влади сприяє взаємодії між законодавчою та виконавчою гілками влади, спонукає уряд до виконання ним своєї програми, розробки необхідних проектів законів та прийняття власних нормативно-правових актів.

Стан дослідження. В вітчизняній юридичній науці питанню парламентської відповідальності, та відповідальності Кабінету Міністрів України перед Верховною Радою України, приділяли увагу С. Сорока, Ю. Барабаш, О. Майданник, О. Совгиря, Р. Павленко та ін. Можна згадати дослідження О. Совгирі, в яких розглядається парламентська відповідальність уряду як одного з елементів його правового статусу; роботи О. Майданник, присвячені аналізу контрольної функції парламенту; в дослідженнях Ю. Барабаша аналізуються проблеми здійснення парламентського контролю в Україні. Однак досліджень, присвячених саме порядку прийняття резолюції (вотуму) недовіри Кабінету Міністрів України, досить мало. У зв’язку з цим, метою нашого дослідження є аналіз парламентської процедури резолюції (вотуму) недовіри уряду України.

Виклад основного матеріалу. В Україні інститут парламентської відповідальності уряду безпосередньо пов'язаний з проблемою вибору оптимальної форми правління та залишається дискусійним (с) Нікіта Лихачов, 2017 
Лихачов Н.

Процедура резолюції (вотуму) недовіри як форма парламентської відповідальності кабінету міністрів України

протягом усього конституційного процесу. В перші роки незалежності конституційну основу організації та діяльності органів державної влади становила Конституція УРСР 1978 р. Її норми передбачали відповідальність Ради Міністрів УРСР перед Верховною Радою УРСР, а в період між сесіями - перед іiі Президією. 3 запровадженням 5 липня 1991 р. посади Президента УРСР як вищої посадової особи Українського держави і глави виконавчої влади, Законом України «Про внесення змін і доповнень до Конституції (Основного Закону) Української РСР» № 1554-ХІІ від 17.09.1991 р. були внесені зміни в ч. 1 ст. 117 Конституції УРСР, відповідно до яких встановлювався принцип відповідальності Кабінету Міністрів України не тільки перед Верховною радою України, а й перед Президентом України [1]. Однак в 1992 р. 3 метою усунення двовладдя в системі виконавчої влади Закон України «Про внесення змін і доповнень до Конституції (Основного Закону) України» № 2113-ХІІ від 14.02.1992 р. передбачив підпорядкованість Кабінету Міністрів України Президенту України і підзвітність і відповідальність його перед Верховною Радою України. Також закон передбачав право Верховної Ради України виразити недовіру Прем’єр-міністру України, окремим членам Кабінету Міністрів України або Кабінету Міністрів України загалом. В такій редакції конституційна норма діяла до прийняття Конституційного договору.

Тривалий конституційний процес та протистояння між гілками влади призвели в 1995 р. до політичної кризи, а потім до укладення Конституційного договору між Верховною Радою України та Президентом України «Про основні засади організації та функціонування державної влади і місцевого самоврядування в Україні на період до прийняття Конституції України» від № 1к/95-ВР. 08.06.1995 р. Ст. 29 Конституційного договору визначала Кабінет Міністрів України як центральний колегіальний орган державної виконавчої влади, підпорядкований Президенту України і відповідальним перед ним [2]. Ст. 33 договору передбачала право Верховної Ради України приймати рішення про вотум недовіри Кабінету Міністрів України загалом чи окремим його членам у разі несвоєчасного подання проекту Державного бюджету України.

3 прийняттям 28.06.1996 р. Конституції України був закріплений принцип відповідальності Кабінету Міністрів України перед Президентом України, а також підконтрольності та підзвітності його Верховній Раді України у межах, передбачених у ст. ст. 85, 87 Конституції України. (ч. 2 ст. 113). Щодо інституту парламентської відповідальності уряду, ч. 1 ст. 87 Основного Закону передбачає, що Верховна Рада України за пропозицією не, менш як однієї третини народних депутатів України від їі конституційного складу може розглянути питання про відповідальність Кабінету Міністрів України та прийняти резолюцію недовіри Кабінету Міністрів України більшістю від конституційного складу Верховної Ради України.

Після проведення Конституційної реформи з прийняттям Закону України «Про внесення змін до Конституції України» № 2222-IV від 08.12.2004 р. та закріпленням такої форми правління, як парламентсько-президентська республіка, ч. 2 ст. 113 Основного Закону було закріплено відповідальність Кабінету Міністрів України перед Президентом України і Верховною Радою України, підконтрольність і підзвітність Верховній Раді України [3]. Також суттєвих змін зазнала ст. 87 Конституції України: серед суб’єктів ініціювання питання про винесення недовіри, крім однієї третини народних депутатів України, був названий і Президент України, а також розширено перелік обмежень для винесення вотуму недовіри уряду. 3 прийняттям Рішення Конституційного Суду №20-рп/2010 від 30.09.2010 р. вищезазначений закон було визнано таким, що не відповідає Конституції України (є неконституційним), у зв’язку з порушенням конституційної процедури його розгляду та прийняття. Наслідком стало повернення України до президентсько-парламентської форми правління та відповідальності уряду в редакції Конституції 1996 р.

3 прийняттям Постанови Верховної Ради України № 750-VII від 22.02.2014 р. було визнано такими, що є чинними на території України, положення Конституції України, прийнятої на п’ятій сесії Верховної Ради України 28 червня 1996 р., зі змінами і доповненнями, внесеними законами України № 2222-IV від 8 грудня 2004 р., від 1 лютого 2011 року № 2952-VI, від 19 вересня 2013 року № 586-VI в Україні було повернено парламентсько-президентську форму правління з властивими їй особливостями парламентської відповідальності уряду. Тому на сьогодні відповідно до ч. 1 ст. 113 Конституції України, Кабінет Міністрів України відповідальний перед Президентом України і Верховною Радою України, підконтрольний і підзвітний Верховній Раді України у межах, передбачених Конституцією.

Наслідком підконтрольності та підзвітності уряду є його відповідальність перед єдиним органом законодавчої влади - Верховною Радою України. Широке використання різних форм парламентської відповідальності (вотуму довіри, резолюції недовіри, імпічменту та ін.) є характерною рисою парламентської та змішаної форм правління. Деякі з цих форм застосовуються в Україні як парламентсько-президентській республіці. Дослідимо ці форми та процедури їх реалізації більш докладно. 
Вважаємо, що під процедурою парламентської відповідальності Кабінету Міністрів України слід розуміти різновид парламентської процедури, що реалізується в передбачених Конституцією та законами України формах та складається із певної послідовності дій Верховної Ради України, спрямованих на прийняття рішення про відставку уряду або його окремих членів з метою забезпечення стабільності та ефективності функціонування вищого органу виконавчої влади. Парламентська відповідальність Кабінету Міністрів України характеризується такими рисами, як:

- за своєю правовою природою може мати як юридичний, так і політичний характер;

- iї форми закріплюється в Конституції України, а процедури їх реалізації в Регламенті Верховної Ради України, Законі України «Про Кабінет Міністрів України» та інших законах;

- може мати як колективний, так й індивідуальний характер;

- метою ii застосування є стабільність та ефективність функціонування не тільки Кабінету Міністрів України, але й усієї системи органів державної влади;

- має взаємний характер, який характеризується правом Президента України достроково припинити повноваження Верховної Ради України, якщо протягом шістдесяти днів після відставки Кабінету Міністрів України парламентом не сформовано персональний склад Кабінету Міністрів України;

- реалізується у певних формах.

Відповідно до ст. 87 ч. 3 ст. 115 Конституції України, такою формою є резолюція недовіри Кабінету Міністрів України. Резолюція недовіри має деструктивний характер і не передбачає обов'язку парламенту пропонувати главу нового вищого органу виконавчої влади одночасно з її прийняттям. Дослідимо процедуру реалізації цієї форми відповідальності Кабінету Міністрів України більш детально.

Відповідно до ч. 1 ст. 87 Конституції України, Верховна Рада України за пропозицією Президента України або не менш, як однісї третини народних депутатів України від конституційного складу Верховної Ради України може розглянути питання про відповідальність Кабінету Міністрів України та прийняти резолюцію недовіри Кабінету Міністрів України більшістю від конституційного складу Верховної Ради України [4]. Слід зазначити, що те, що резолюція недовіри, яка має наслідком відставку Кабінету Міністрів України, може здійснюватись Верховною Радою України за безпосередньої ініціативи Президента України $є$ достатньо специфічною, властивою саме для національного законодавства.

Відповідно до Регламенту Верховної Ради України, процедура винесення резолюції недовіри складається $з$ таких етапів:

- підготовка до розгляду Верховною Радою питання про відповідальність Кабінету Міністрів України. Цей етап, відповідно до ст. 231 Регламенту Верховної Ради, України складається з таких підетапів:

а) ініціювання питання про відповідальність Кабінету Міністрів України. Питання про відповідальність уряду виноситься на розгляд парламенту за пропозицією не менш, як однієї третини народних депутатів від його конституційного складу, підтриманою їх підписами. Крім того, така пропозиція згідно 3 вищезазначеними положеннями Конституції України та ч. 1 ст. 14 Закону України «Про Кабінет Міністрів України», може бути винесена й Президентом України. Це питання включається до порядку денного сесії Верховної Ради без голосування;

б) формулювання комітетами парламенту запитань до уряду. Після внесення на розгляд Верховної Ради питання про відповідальність Кабінету Міністрів України комітети, відповідно до предметів їх відання не пізніше, як у чотириденний строк, формулюють і направляють через Апарат Верховної Ради питання до Кабінету Міністрів України, на які вони хотіли б отримати відповіді до розгляду питання про відповідальність Кабінету Міністрів України (ч. 2 ст. 231 Регламенту Верховної Ради України);

в) підготовка і направлення урядом інформації щодо порушених питань. Кабінет Міністрів України у триденний строк після отримання запитань від комітетів направляє комітетам відповіді на них. Інформацію з питання про відповідальність Кабінету Міністрів згідно з ч. 2 параграфа 135 Регламенту Кабінету Міністрів України готують визначені Прем'єр-міністром центральні органи виконавчої влади [5]. Узагальнений варіант інформації Кабінету Міністрів України разом з відповідями на запитання, що надійшли від комітетів, направляється до Апарату Верховної Ради, після чого у терміновому порядку надається народним депутатам;

г) розгляд на рівні комітетів Верховної Ради України питання про відповідальність уряду. Після отримання відповідей на поставлені запитання комітети розглядають питання про відповідальність Кабінету Міністрів України на своїх засіданнях. За результатом розгляду такого питання комітет, відповідно до п. 2 ч. 1 ст. 25 Закону України «Про комітети Верховної Ради України», приймає рекомендації. Також комітети мають право виступу представника від комітету на пленарному засіданні при розгляді Верховною 
Лихачов Н.

Процедура резолюції (вотуму) недовіри як форма парламентської відповідальності кабінету міністрів України

Радою України питання щодо резолюції недовіри (ч. 4 ст. 231 Регламенту Верховної Ради України). На цьому підетапі, як зазначають С. В. Лінецький та В. П. Крижанівський, забезпечується можливість отримання інформації від Уряду стосовно найважливіших аспектів його діяльності, зокрема тих, які стали фактичними (правовими) підставами для формулювання подання щодо його відповідальності перед парламентом України [6, с. 595];

д) включення питання про відповідальність Кабінету Міністрів України до порядку денного сесії Верховної Ради України. Питання про відповідальність Кабінету Міністрів України розглядається на пленарному засіданні Верховної Ради не пізніше, ніж через 10 днів після внесення пропозицій (ч. 4 ст. 231 Регламенту Верховної Ради України).

- Наступний етап - розгляд Верховною Радою питання про відповідальність Кабінету Міністрів України. На пленарне засідання Верховної Ради України запрошуються всі члени Кабінету Міністрів України. У разі розгляду питання про відповідальність Кабінету Міністрів України за пропозицією Президента України у пленарному засіданні Верховної Ради України бере участь Президент України. Складається 3 таких підетапів:

а) доповідь ініціатора питання про відповідальність уряду. Відповідно до ч. 1 ст. 232 Регламенту Верховної Ради України, розгляд питання про відповідальність Кабінету Міністрів України починається 3 доповіді народного депутата, уповноваженого з числа народних депутатів, які ініціювали питання про відповідальність Кабінету Міністрів України. Для доповіді надається до 45 хвилин. Після закінчення доповіді доповідач протягом 45 хвилин відповідає на усні запитання представників депутатських фракцій (депутатських груп) та інших народних депутатів;

б) виступ глави уряду. Під час розгляду питання про відповідальність Кабінету Міністрів на пленарному засіданні Верховної Ради виступає Прем’єр-міністр. Слово для виступу надається Прем'єрміністру України, а в разі його відсутності з поважних причин - Першому віце-прем'єр-міністру України після закінчення відповідей на запитання до 45 хвилин. Крім того, на пропозицію депутатської фракції (депутатської групи), комітету Верховна Рада може прийняти рішення про заслуховування інформації членів Кабінету Міністрів України. Для інформації члену Кабінету Міністрів України надається до 15 хвилин. Після інформації член Кабінету Міністрів України протягом 15 хвилин відповідає на запитання представників депутатських фракцій (депутатських груп);

в) виступи представників комітетів та депутатських фракцій. Після доповіді та відповідей на запитання надається слово для виступу представникам комітетів та депутатських фракцій (депутатських груп) тривалістю до трьох хвилин;

г) голосування щодо прийняття резолюції недовіри. Після закінчення обговорення проводиться голосування Кабінету Міністрів України. Резолюція недовіри Кабінету Міністрів України вважається прийнятою, якщо за неї проголосувала більшість народних депутатів від конституційного складу Верховної Ради. Таке рішення приймається шляхом відкритого поіменного голосування. Прийняття Верховною Радою України резолюції недовіри Кабінету Міністрів України має наслідком відставку Кабінету Міністрів України (ч. ч. 4, 5 Регламенту Верховної ради України [7].

Якщо звернутися до практики використання процедури парламентської відповідальності уряду України у формі резолюції недовіри, можна навести такі приклади його успішного використання:

- 26 квітня 2001 р. парламентом було оголошено недовіру прем’єрові В. Ющенку (Резолюція про недовіру Кабінетові Міністрів України від 26.04.2001 № 2393-III). Підставою прийняття резолюції було те, що 17 квітня 2001 р. Верховна Рада України заслухала звіт Кабінету Міністрів України про хід виконання програми діяльності уряду. За результатами розгляду звіту роботу уряду було визнано незадовільною та зазначено, що здійснення урядової програми «Реформи заради добробуту» призвело не до стабілізації у вітчизняній економіці, а до загострення соціально-економічні проблеми в суспільстві [8]. Наслідком прийняття резолюції недовіри стало підписання 28 квітня 2001 р. Указу Президента України «Про відставку Кабінету Міністрів України»;

- 3 березня 2010 р., розглянувши питання про відповідальність Кабінету Міністрів України за соціально-економічну ситуацію в Україні, Верховна Рада України прийняла резолюцію недовіри уряду Ю. Тимошенко (Постанова Верховної Ради України «Про відповідальність Кабінету Міністрів України» № 1928-VI від 3 березня 2010 р.).

Для забезпечення політичної стабільності й попередження занадто частої зміни урядів Конституцією та законами України, передбачені певні обмеження щодо застосування процедури парламентської відповідальності уряду у формі резолюції недовіри, у тому числі й у разі відхилення питання про недовіру 
уряду. Метою застосування таких обмежень, як зазначає Р. С. Мартинюк, є забезпечення оптимального балансу між стабільністю кабінету та його відповідальністю. Уряди можуть бути відповідальними і водночас стабільними, якщо процедура їх відповідальності перед парламентом є складною і обмежена низкою умов [9]. Зокрема, відповідно до ч. 2 ст. 87 Конституції України та ч. 5 ст. 14 Закону України «Про Кабінет Міністрів України», питання про відповідальність Кабінету Міністрів України не може розглядатися Верховною Радою України більше одного разу протягом однієї чергової сесії, а також протягом року після схвалення Програми діяльності Кабінету Міністрів України або протягом останньої сесії Верховної Ради України.

Слід зазначили, що конституціями більшості зарубіжних держав передбачена ситуація, коли повторно пропозицію про вотум недовіри може бути внесено і до закінчення встановленого конституцією терміну, зокрема, якщо ініціатором резолюції недовіри виступає більша кількість депутатів, ніж при винесенні попередньої резолюції (зокрема, 115 членів Сейму Польщі, абсолютна більшість загального числа депутатів парламенту Греції тощо). На необхідності законодавчого закріплення можливості подолання мораторію на заборону ставити питання про недовіру уряду протягом певного часу або в певних ситуаціях наполягають й українські вчені-конституціоналісти. Зокрема, на думку Р. М. Павленка, слід змінити положення ст. 87 Конституції України щодо неможливості розгляду питання про оголошення уряду вотуму недовіри протягом однієї сесії або року з дня затвердження Програми діяльності Кабінету Міністрів: передбачити можливість постановки такого питання навіть за означених умов - але тільки в разі, якщо цю пропозицію підтримують не менше 3/5 від конституційної кількості депутатів палати [10, с. 211-212]. Як зазначає з цього природу Р. С. Мартинюк, доцільно відмовитися від імперативного характеру мораторію на право Верховної Ради України висловлювати резолюцію недовіри Кабінету Міністрів України більше одного разу протягом однієї чергової сесії, а також протягом року після схвалення Програми діяльності Кабінету Міністрів України або протягом останньої сесії Верховної Ради України. Адже в діяльності Уряду можуть бути виявлені такі порушення Програми його діяльності: зловживання прем'єром владою, загальний і безсумнівний неуспіх урядової політики тощо, які стануть достатньо вагомими причинами таких екстраординарних дій Верховної Ради України [11, с. 91]. Підтримує точку зору науковців й О. В. Совгиря $[12$, с. 32].

Підтримуючи вищезазначених науковців, вважаємо за необхідне змінити положення ст. 87 Конституції щодо неможливості розгляду питання про прийняття резолюції недовіри протягом однісї сесії або року з дня затвердження Програми діяльності Кабінету Міністрів: передбачити можливість постановки такого питання навіть за означених умов - але в тому разі, якщо ця пропозиція буде винесена більшістю, а прийнята 2/3 від конституційного складу Верховної Ради України.

За характером суб'єкта відповідальності парламентська відповідальність може мати не тільки колективний, але й індивідуальний характер, коли недовіру може бути висловлено не тільки уряду загалом, а й окремим міністрам. Це надає можливість контролювати якість роботи окремих міністерств, не вдаючись до відставки усього уряду. Можливість індивідуальної парламентської відповідальності міністра існує в Австрії, Великобританії, Італії, Латвії, Польщі, Греції та закріплюється конституціями цих держав. Ст. 87 Конституції України не передбачає винесення резолюції недовіри окремому члену Кабінету Міністрів України. Хоча п. 12 ст. 85 Основного Закону передбачається, що до повноважень Верховної Ради України належить вирішення питання про відставку Прем’єр-міністра України, членів Кабінету Міністрів України. Крім того, згідно зі ст. 18 Закону України «Про Кабінет Міністрів України», член Кабінету Міністрів України (крім Прем’єр-міністра України) може бути звільнений з посади Верховною Радою України:

1) шляхом прийняття відставки члена Кабінету Міністрів України за поданою ним заявою про відставку;

2) за поданням Прем’єр-міністра України (стосовно Міністра закордонних справ України та Міністра оборони України таке подання вноситься за згодою Президента України);

3) за поданням Президента України - Міністр закордонних справ України та Міністр оборони України;

4) за власною ініціативою [13].

Таким чином, п. 4 ст. 18 вищезазначеного закону, передбачаючи право Верховної Ради України звільняти членів Кабінету Міністрів України за власною ініціативою, закріплює саме таку форму парламентської відповідальності, як індивідуальний вотум (резолюція) недовіри. Цей інститут, на думку I. Б. Коліушко, є надзвичайно важливим, підкреслює політичну сутність посади члена уряду, дає змогу окреслити межі політичної відповідальності цієї особи лише тими діями, які вона вчиняє чи на які погоджується [14, с. 10]. 
Лихачов Н.

Процедура резолюції (вотуму) недовіри як форма парламентської відповідальності кабінету міністрів України

Підстави парламентської відповідальності члену уряду встановлюються ст. 45 Закону України «Про Кабінет Міністрів України». Зокрема, згідно з ч. ч. 2-4 ст. 45 вищезазначеного закону, члени Кабінету Міністрів України особисто несуть відповідальність за стан справ у доручених їм сферах державного управління. Члени Кабінету Міністрів України за вчинення правопорушень несуть відповідальність відповідно до закону. Члени Кабінету Міністрів України за вчинення корупційних правопорушень або порушення вимог до поведінки осіб, уповноважених на виконання функцій держави (заборона використання службового становища в особистих цілях, запобігання конфлікту інтересів тощо), можуть бути звільнені Верховною Радою України в порядку, визначеному частиною першою статті 18 Закону [13]. Однак процедури його прийняття законом майже не встановлено. Частинами 2, 3 ст. 18 лише закріплюється, що Рішення Верховної Ради України про звільнення з посади члена Кабінету Міністрів України приймається у формі постанови Верховної Ради України. Член Кабінету Міністрів України звільняється 3 посади 3 дня прийняття відповідного рішення Верховною Радою України.

Вважаємо, що ця прогалина в законодавстві має бути усунена таким шляхом: право Верховної Ради України щодо прийняття резолюції недовіри члену Кабінету Міністрів України більшістю від конституційного складу Верховної Ради України має бути встановлено в Конституції України; процедура винесення такої резолюції повинна закріплюватися Регламентом Верховної Ради України.

Вважаємо що зміни, запропоновані нами щодо процедури резолюції недовіри уряду України сприятимуть поліпшенню якості парламентської відповідальності Кабінету Міністрів України більш конструктивній взаємодії між ним та парламентом, створять належні стимули до ефективної діяльності вищого органу виконавчої влади.

\section{Список використаної літератури}

1. Про внесення змін і доповнень до Конституції (Основного Закону) Украӥнської РСР : Закон України № 1554-XII від 17.09.1991 p. [Електронний ресурс]. - Режим достуny : http://zakon3.rada.gov.ua/laws/ show/1554-12.

2. Про основні засади організації та функиіонування державної влади і місиевого самоврядування в Украӥні на період до прийняття Конституизї України : Конституиійний договір між Верховною Радою України та Президентом України № 1к/95-ВР від 08.06.1995 p. [Електронний ресурс]. - Режим доступу : httр:// zakon2.rada.gov.ua/laws/show/1\%D0\%BA/95-\%D0\%B2\%D1\%80.

3. Про внесення змін до Конституції України : Закон України № 2222-IV від 08.12.2004 р. ВР [Електронний ресурс]. - Режим достуny : http://zakon2.rada.gov.ua/laws/show/254\%D0\%BA/96-\%D0\%B2\%D1\%80/ ed20060101/page2.

4. Конституція Украӥни : № 254к/96-ВР від 28.06.1996 р. [Електронний ресурс]. - Режим доступу : http://zakon2.rada.gov.ua/laws/show/254\%D0\%BA/96-\%D0\%B2\%D1\%80.

5. Про затвердження Регламенту Кабінету Міністрів України : Постанова Кабінету Міністрів України № 950 від 18.07 .2007 p. [Електронний ресурс]. - Режим доступy : http://zakon2.rada.gov.ua/laws/ show/950-2007-\%D0\%BF/ page5.

6. Коментар до Регламенту Верховної Ради Украӥни / Лінецький С. В., Крижсанівський В. П.. - К., 2015. - 730 с.

7. Регламент Верховної Ради України : № 1861-VI від 10.02.2010 р. [Електронний ресурс]. - Режим доcmyny : http://zakon2.rada.gov.ua/laws/show/1861-17.

8. Про недовіру Кабінетові Міністрів України : Резолюиія ВерховноїРади Украӥни№ 2393-III від 26.04.2001 р. [Електронний ресурс]. - Режим доступy : http://zakon3.rada.gov.ua/laws/show/2393-14.

9. Мартинюк Р. С. Парламентська відповідальність уряду в зарубіжній та вітчизняній практиці: компаративний аналіз [Електронний ресурс]. - Режим доступу : http://naub.org.ua/?p=1171.

10. Павленко Р. М. Парламентська відповідальність уряду: світовий та украӥнський досвід / Р. М. Павленко. К. : КМ Академія, 2002. - 253 с.

11. Мартинюк Р. Інститут парламентської відповідальності уряду в Україні за змістом Конституції України в редакиії від 8 грудня 2004 р. // Вісник Академії правових наук України. - 2007. - № 4 (51). - С. 84-91.

12. Совгиря О. В. Парламентська відповідальність Кабінету Міністрів України: теоретичні та практичні аспекти // Адвокат. - 2012. - № 12 (147). - C. 28-35.

13. Про Кабінет Міністрів Украӥни : Закон Украӥни № 794-VII від 27.02.2014 р. [Електронний ресурс]. Режим доступy : http://zakon3.rada.gov.ua/laws/ show/794-18.

14. Коліушко I. Б. Про запровадження у сферу виконавчої влади посад державних політичних діячів / I. Коліушко, В. Тимошук // Право Украӥни. - 2000. - № 2. - С. 10-12. 


\section{References}

1. Pro vnesennya zmin i dopovnen' do Konstytutsiyi (Osnovnoho Zakonu) Ukrayins'koyi RSR. Zakon Ukrayiny № 1554-XII [On amendments and additions to the Constitution (Basic Law) of the Ukrainian SSR. Law of Ukraine № 1554-XII]. (1991, 17 September). (n.d.). zakon.rada.gov.ua. Retrieved from http://zakon3.rada. gov.ua/laws/show/1554-12 [in Ukrainian].

2. Pro osnovni zasady orhanizatsiyi ta funktsionuvannya derzhavnoyi vlady $i$ mistsevoho samovryaduvannya $v$ Ukrayini na period do pryynyattya Konstytutsiyi Ukrayiny. Konstytutsiynyy dohovir mizh Verkhovnoyu Radoyu Ukrayiny ta Prezydentom Ukrayiny № $1 \mathrm{k} / 95$-VR [About the basic principles of organization and functioning of the state power and local self-government in Ukraine for the period before the adoption of the Constitution of Ukraine. Constitutional agreement between the Verkhovna Rada of Ukraine and the President of Ukraine № 1k/95-VR]. (1995, 08 June). (n.d.). zakon.rada.gov.ua. Retrieved from http://zakon2.rada.gov. ua/laws/show/1\%D0\%BA/95-\%D0\%B2\%D1\%80 [in Ukrainian].

3. Pro vnesennya zmin do Konstytutsiyi Ukrayiny. Zakon Ukrayiny № 2222-IV [On amendments to the Constitution of Ukraine. Law of Ukraine№ 2222-IV]. (2004, 08 December). (n.d.). zakon.rada.gov.ua. Retrieved from http:// zakon2.rada.gov.ua/laws/show/254\%D0\%BA/96-\%D0\%B2\%D1\%80/ ed20060101/page2 [in Ukrainian].

4. Konstytutsiya Ukrayiny [The Constitution of Ukraine]. (1996, 28 June). (n.d.). zakon.rada.gov.ua. Retrieved from http://zakon2.rada.gov.ua/laws/show/254\%D0\%BA/96-\%D0\%B2\%D1\%80 [in Ukrainian].

5. Pro zatverdzhennya Rehlamentu Kabinetu Ministriv Ukrayiny. Postanova Kabinetu Ministriv Ukrayiny № 950 [On Approval of the Regulation of the Cabinet of Ministers of Ukraine. Resolution of the Cabinet of Ministers of Ukraine № 950]. (2007, 18 July) (n.d.). zakon.rada.gov.ua. Retrieved from http://zakon2.rada.gov.ua/laws/ show/950-2007-\%D0\%BF/ page5 [in Ukrainian].

6. Linets'kyy, S.V., Kryzhanivs'kyy, V.P. (Edt.). (2015). Komentar do Rehlamentu Verkhovnoyi Rady Ukrayiny [Commentary to the Rules of Procedure of the Verkhovna Rada of Ukraine]. K. [in Ukrainian].

7. Rehlament Verkhovnoyi Rady Ukrayiny № 1861-VI [Rules of the Verkhovna Rada of Ukraine № 1861-VI]. (2010, 10 February). (n.d.). zakon.rada.gov.ua. Retrieved from http://zakon2.rada.gov.ua/laws/show/1861-17 [in Ukrainian].

8. Pro nedoviru Kabinetovi Ministriv Ukrayiny. Rezolyutsiya Verkhovnoyi Rady Ukrayiny № 2393-III [About mistrust of the Cabinet of Ministers of Ukraine. Resolution of the Verkhovna Rada of Ukraine № 2393-III]. (2001, 26 April). (n.d.). zakon.rada.gov.ua. Retrieved from http://zakon3.rada.gov.ua/laws/show/2393-14 [in Ukrainian].

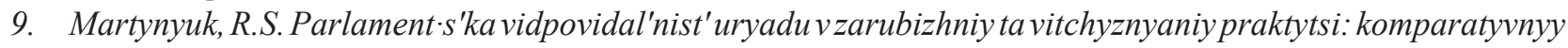
analiz [Parliamentary responsibility of the government in foreign and domestic practice: comparative analysis]. Retrieved from http://naub.org.ua/?p=1171 [in Ukrainian].

10. Pavlenko, R. M. (2002). Parlament $\cdot s$ 'ka vidpovidal'nist'uryadu: svitovyy ta ukrayins'kyy dosvid [Parliamentary responsibility of the government: world and Ukrainian experience]. K.: KM Akademiya [in Ukrainian].

11. Martynyuk, R. (2007). Instytut parlaments'koyi vidpovidal'nosti uryadu v Ukrayini za zmistom Konstytutsiyi Ukrayiny v redaktsiyi vid 8 hrudnya 2004 r. [Institute of Parliamentary Liability of the Government in Ukraine in the Context of the Constitution of Ukraine in the wording of December 8, 2004]. Bulletin of the Academy of Legal Sciences of Ukraine - Visnyk Akademiyi pravovykh nauk Ukrayiny, 4 (51), 84-91 [in Ukrainian].

12. Sovhyrya, O.V. (2012). Parlament $\cdot s$ 'ka vidpovidal'nist' Kabinetu Ministriv Ukrayiny: teoretychni ta praktychni aspekty [Parliamentary responsibility of the Cabinet of Ministers of Ukraine: theoretical and practical aspects]. Advokat-Lawyer, 12 (147), 28-35 [in Ukrainian].

13. Pro Kabinet Ministriv Ukrayiny. Zakon Ukrayiny № 794-VII [About the Cabinet of Ministers of Ukraine. Law of Ukraine № 794-VII]. (2014, 27 February). (n.d.). zakon.rada.gov.ua. Retrieved from http://zakon3.rada. gov.ua/laws/ show/794-18 [in Ukrainian].

14. Koliushko, I.B. (2000). Pro zaprovadzhennya u sferu vykonavchoyi vlady posad derzhavnykh politychnykh diyachiv [On introduction of positions of state politicians in the sphere of executive power]. Pravo Ukrayiny The Law of Ukraine, 2, 10-12 [in Ukrainian].

Стаття надійшла до редакції 06.12.2017. 